\title{
Bank Capital and Profitability: An Empirical Study of South African Commercial Banks
}

\author{
Charles Nyoka \\ Ph.D., Senior Lecturer, Department of Finance Risk Management and Banking \\ University of South Africa, Pretoria, South Africa \\ e-mail:nyokac@unisa.ac.za or charlesnyoka@yahoo.co.uk
}

\begin{abstract}
Bank capital is a principal aspect of regulation and will determine how long a bank remains in business from a regulatory point of view. Prior research on the relationship between capital and profitability has largely focused on developed economies, especially the USA, and Europe and the results have been inconclusive. There is no evidence of such research done to date that focuses on an emerging economy such as South Africa. Using South Africa as a unit of analysis and using the Generalised Methods of Moments (GMM), and Panel Two Stage Least Squares (2SLS) or Pooled IV method as the estimation techniques, this study tested the hypothesis that there is a positive and statistically significant relationship between bank capital and profitability. The results provided evidence of a positive relationship between capital ratio (CAR), return on equity (ROE) and return on assets (ROA). From a bank specific strategic decision-making perspective, this would assist financial institutions and investors in tailoring investment decisions in response to policy decisions that relate to bank capital. From the public policy perspective, this would assist both governments and regulators in formulating better- informed policy decisions regarding the importance of bank capital.
\end{abstract}

Keywords: capital, South Africa, return on capital, Pooled IV , regression, analysis

JEL: G21, N27 


\section{Introduction}

Debate and studies around the subject of capital and profitability of banks have been carried out at international, regional and domestic levels (Curak, Poposki \& Pupur 2011). However, there are no known studies of this relationship having been carried out in a developing country like South Africa. Akinboade and Makina (2006:125); bemoan the lack of concerted effort to develop the financial sector further and the inability of the banking sector to introduce new non-deposit financial products in order to attract more savings from the wider population.

Using South African banks as a unit of analysis, this study tested the hypothesis that there is a positive and statistically significant relationship between bank capital and profitability over the period 2006 to 2015 .

\section{Empirical Review of Literature on Banks' Profitability}

Conventional theory and empirical work on bank profitability suggest that bank profitability is determined by various firm-specific, industry-specific and macro-economic variables (Curak, Poposki \& Pupur 2011).

There has been a debate on whether capital plays a role in curbing excessive risk taking by banks and reducing the probability of bankruptcy. The orthodox argument (Berger, Herring \& Szego 1995; Kaufman 1991; Furlong \& Keeley 1989; Furlong 1990) is that capital acts as a buffer against failure, and therefore regulation that forces banks to hold more capital will reduce the likelihood of bankruptcy. Other authors (Kahane 1977; Koen \& Santomero 1980) disagree and suggest that capital regulation may indeed lead to increased risk taking by banks.

Conventional wisdom suggests that the riskiness of a bank is determined by its ability to absorb unforeseen losses. Given that capital is viewed to act as a buffer against losses, a high capital asset ratio (CAR) tends to be associated with lower profitability. Researchers such as Dietrich and Wanzenried (2009), Athanasoglou, Brissimis and Delis (2005), Athanasoglou et al. (2008), Kosmidou et al. (2006), Flaminin et al. (2009), (2000), Athanasoglou et al. (2005) argue for the significance of equity capital as a key determinant to profitability. Dietrich and Wanzenried (2009:34) analyse the profitability of commercial banks in Switzerland during the period from 1999 to 2006 . They find that better- capitalised banks seemed to be more profitable. In addition, in the case where the loan volume of a bank grows faster than the market, this has an impact on bank profitability. Athanasoglou, Brissimis and Delis (2005:134) analyse the effect of a selected set of determinants on bank profitability in Greece. They find that capital is important in explaining bank profitability and that increased exposure to credit risk lowers profits.

Javaid, Anwar and Gafoor (2011:69) analyse the determinants of bank profitability in Pakistan during the period 2004 to 2008. They find that the characteristics of individual banks 
(internal factors only) are considered determinants of bank profitability in Pakistan. In addition, banks with more equity capital, total assets, loans and deposits are perceived to have more security, and such an advantage can be translated into higher profitability.

KPMG (1998:53) focuses on bank margins and their relationship to profitability for the four major banks in the South African market. The ROE is identified as being the significant performance measure and the profitability is reviewed on this basis. Athanasoglou et al. (2008:134) examine the effect of bank-specific, industry-specific and macro-economic determinants on the profitability of Greek banks over the period 1985 to 2001. They find that capital is important in explaining bank profitability and that increased exposure to credit risk lowers profits. Additionally, labour productivity growth has a positive and significant impact on profitability while operating expenses are negatively and strongly linked to it, showing that cost decisions of bank management are instrumental in influencing bank performance.

\section{Other Determinants of Bank Performance}

Capital as measured by the present regulatory framework, though important, is not the only factor that determines the profitability of a bank. Much also depends on the quality of the assets of the bank and, importantly, the level of provisioning a bank may be holding outside its capital against assets of doubtful value.

Other than capital, the quality of assets and the level of provisioning, there are also other determinants of bank performance that are worthy of discussion.

Researchers, such as Short (1979), Demirguc-Kunt and Huizinga (1999, 2000), and Bikker and $\mathrm{Hu}$ (2002) examined and compared the determinants of profitability across different countries, while authors such as Athanasoglou, Brissimis and Delis (2005, Berger (1995a, 1995b), Goddard, Molyneux, and Wilson (2004a, 2004b) focused on the banking sectors of individual countries. However, there is a relatively common list of factors that are advanced in recent literature as the usual determinants of bank profitability. An observation is made in most of the studies around the topic of capital and profitability that the factors can broadly be grouped into two, internal factors and external factors (Alper \& Adbar 2011).

Gungor (2007) describes internal determinants as being related to bank management and referred to them as micro or bank-specific determinants of profitability. According to Gungor (2007), external determinants are reflective of the economic and legal environment that affects the operation and performance of banks. Mamatzakis and Remoundos (2003) conclude that the variables that are directly related to the strategic planning of the banks that cover, among others, personnel expenses, loans-to-assets ratio, and equity-to-assets ratio are responsible for the profit levels shown in their studies.

The pair also report that economies of scale play a significant role in the market, and has a positive impact on profitability. In their study, Mamatzakis and Remoundos 
also find that the size of the market, an external variable, defined by the supply of money, significantly influences profitability. The findings by Afanasieff et al. (2002) who examined the determinants of the interest spreads of banks in Brazil suggested that both macro and micro variables have the most impact on bank interest spread. Naceur (2003) who investigates the impact of the characteristics of banks, capital structure and macro-economic indicators on the net interest margin and profitability of banks in the Tunisian banking industry for the 1983-2000 period, concludes that high net interest margin and profitability tend to be associated with banks that hold a relatively large amount of capital, and do not have large overheads. In research conducted in Switzerland, Dietrich and Wanzenried (2009) find significant differences in profitability between commercial banks and argued that the differences can largely be explained by the factors that they cover in their studies.

These factors revolved around capitalisation and the results support the notion that better-capitalised banks are more profitable than other banks. They also touched on the loan volume of the bank and conclude that if the loan volume of a bank is growing at a faster rate than the rest of the market, the impact on bank profitability is positive.

The other factors that make it on the list are credit risk, operating expenses, market concentration, economic growth and inflation, which have been debated in the literature and have been incorporated because of their significance to the econometric model used.

\section{Methodology and Data Sources}

The study used cross-sectional time-series annual data for thirteen banks ( $n=13$ ) during the sample period from 2006 to 2015 ( $\mathrm{T}=10$ ), yielding one hundred and thirty total observations $(\mathrm{N}=130)$. Annual data on return on equity (ROE), return on assets (ROA), capital-to-asset ratio (CAR), size, operating expenses, credit risk (CR), gross domestic product (GDP), consumer price index (CPI), Herfindahl-Hirschman Index (HHI) and stock were used for econometric modelling. Data on all the variables were obtained from numerous sources, which include Bank scope, Bloomberg, the financial statements of the banks concerned and the Reserve Bank quarterly reports for the entire duration of the study period from 2006 to 2015.

The estimation techniques applied in the econometric estimation process are the generalised methods of moments (GMM), and panel two-stage least squares (2SLS) or the pooled IV method. The statistical evaluation and estimation technique selection procedure of the panel 2SLS or pooled IV regression, GLS random effects (RE) model and fixed effects (FE) model was undertaken based on the Hausman-test approach. The respective equations are listed below: 


\section{Panel 2SLS or Pooled IV}

$$
\mathrm{Y}_{\mathrm{it}}=\alpha+\mathrm{X}_{\mathrm{it}}^{\prime} \beta\left(\alpha_{\mathrm{i}}-\alpha+\mathrm{e}_{\mathrm{it}}\right)
$$

\section{Two-Stage Least Squares (2SLS) RegreEGRESSION ANALYSIS}

\section{Random Effects (RE) Model}

$$
\mathrm{Y}_{\mathrm{it}}=\alpha+\mathrm{X}_{\mathrm{it}}^{\prime} \beta+\left(\mathrm{u}_{\mathrm{i}}+\mathrm{v}_{\mathrm{it}}\right) ; \mathrm{v}_{\mathrm{it}} \sim \operatorname{IID}\left(0, \sigma_{\mathrm{v}}^{2}\right)
$$

\section{Fixed Effects (FE) Model}

$$
\mathrm{Y}_{\mathrm{Iit}}=\alpha_{\mathrm{i}}+\mathrm{X}_{\mathrm{it}}^{\prime} \beta+\mathrm{u}_{\mathrm{i}}+\mathrm{e}_{i t}
$$

For all the above three models, $Y_{i t}$ signifies the dependent variable, $\alpha$ denotes the constant, $X_{i t}^{\prime}$ represents a vector of regressors influencing the dependent variable, $\beta$ denotes the estimated coefficient and $e_{i t}$ denotes the error term.

The Hausman-test was performed to choose between the RE model and the FE model based on the specification:

$$
\mathrm{H}=\left(\hat{\beta}_{\mathrm{FE}}-\hat{\beta}_{\mathrm{RE}}\right)^{\prime}\left[\left(\mathrm{V}\left(\hat{\beta}_{\mathrm{FE}}\right)-\mathrm{V}\left(\hat{\beta}_{\mathrm{RE}}\right)^{\wedge}(-1)\right)\right]\left(\hat{\beta}_{\mathrm{FE}}-\hat{\beta}_{\mathrm{RE}}\right)
$$

\section{Generalised Method of Moments}

$$
\mathrm{Y}_{\mathrm{Iit}}=\mathrm{X}^{\prime} \beta+\mathrm{u}_{\mathrm{i}}, \mathrm{u} \sim(0, \Omega)
$$

The $\mathrm{X}^{\prime}$ vector denotes a vector of regressors-, in which the lagged dependent variable was also integrated as a covariate. 


\section{Pooled IV Profitability Functions}

Variable descriptions are as shown in the table below, and the Equations are as given after the table below.

Table 1. Definitions of variables used in the study

\begin{tabular}{|c|l|l|}
\hline $\begin{array}{c}\text { Variable } \\
\text { number }\end{array}$ & \multicolumn{1}{|c|}{$\begin{array}{c}\text { Independent } \\
\text { Variables }\end{array}$} & \multicolumn{1}{c|}{ Definition } \\
\hline 1 & $\begin{array}{l}\text { Capital asset ratio } \\
\text { (CAR) }\end{array}$ & $\begin{array}{l}\text { Defined as the ratio of capital to total risk-weighted assets } \\
\text { (tier 1 capital + tier 2 capital/total risk-weighted assets) }\end{array}$ \\
\hline 2 & $\begin{array}{l}\text { Return on equity } \\
\text { (ROE) }\end{array}$ & $\begin{array}{l}\text { Defined as the ratio of net profit to total equity (net profit/total eq- } \\
\text { uity). }\end{array}$ \\
\hline 3 & $\begin{array}{l}\text { Return on assets } \\
\text { (ROA) }\end{array}$ & $\begin{array}{l}\text { Defined as the ratio of net profit to total assets (net profit/total as- } \\
\text { sets) }\end{array}$ \\
\hline 4 & Size & $\begin{array}{l}\text { Proxy for size defined as the square of the natural logarithm of total } \\
\text { assets -In(total asset)2 }\end{array}$ \\
\hline 5 & $\begin{array}{l}\text { Operating } \\
\text { expenses (OE) }\end{array}$ & $\begin{array}{l}\text { Ratio of operating expenses to total assets (operating expenses/to- } \\
\text { tal assets) }\end{array}$ \\
\hline 7 & $\begin{array}{l}\text { Credit risk (CR) } \\
\text { Gross domestic } \\
\text { product (GDP) }\end{array}$ & $\begin{array}{l}\text { Proxy for credit risk, defined as the ratio of loan loss provisions } \\
\text { to total loans (Loan loss provisions/total loans) }\end{array}$ \\
\hline Annual growth in real gross domestic product \\
\hline
\end{tabular}

No-Lagged Dependent Variables

Source: own study.

$$
\begin{gathered}
\mathrm{ROE}_{\mathrm{it}}=\alpha+\beta_{1}(\mathrm{CAR})+\beta_{2}(\mathrm{CR})+\beta_{3}(\mathrm{Size})+ \\
\beta_{4}(\mathrm{OE})+\beta_{5}(\mathrm{GDP})+\beta_{6}(\mathrm{CPI})+\beta_{7}(\mathrm{HHI})+\mathrm{u}_{\mathrm{it}} \\
\mathrm{ROA}_{\mathrm{it}}=\alpha+\beta_{1}(\mathrm{CAR})+\beta_{2}(\mathrm{CR})+\beta_{3}(\mathrm{Size})+ \\
\beta_{4}(\mathrm{OE})+\beta_{5}(\mathrm{GDP})+\beta_{6}(\mathrm{CPI})+\beta_{7}(\mathrm{HHI})+\mathrm{u}_{\mathrm{it}}
\end{gathered}
$$

\section{Lagged Dependent Variables}

$$
\begin{gathered}
\mathrm{ROE}_{\mathrm{it}}=\alpha+\theta(\mathrm{ROE})_{\mathrm{t}-1}+\beta_{1}(\mathrm{CAR})+\beta_{2}(\mathrm{CR})+\beta_{3}(\mathrm{Size})+ \\
\beta_{4}(\mathrm{OE})+\beta_{5}(\mathrm{GDP})+\beta_{6}(\mathrm{CPI})+\beta_{7}(\mathrm{HHI})+\mathrm{u}_{\mathrm{it}} \\
\mathrm{ROA}_{\mathrm{it}}=\alpha+\theta(\mathrm{ROA})_{\mathrm{t}-1}+\beta_{1}(\mathrm{CAR})+\beta_{2}(\mathrm{CR})+\beta_{3}(\mathrm{Size})+ \\
\beta_{4}(\mathrm{OE})+\beta_{5}(\mathrm{GDP})+\beta_{6}(\mathrm{CPI})+\beta_{7}(\mathrm{HHI})+\mathrm{u}_{\mathrm{it}}
\end{gathered}
$$




\section{GMM Profitability Functions}

\section{No-Lagged Dependent Variables}

$$
\begin{gathered}
\mathrm{ROE}_{\mathrm{it}}=\alpha+\beta_{1}(\mathrm{CAR})+\beta_{2}(\mathrm{CR})+\beta_{3}(\mathrm{Size})+ \\
\beta_{4}(\mathrm{OE})+\beta_{5}(\mathrm{GDP})+\beta_{6}(\mathrm{CPI})+\beta_{7}(\mathrm{HHI})+\mathrm{u}_{\mathrm{it}} \\
\mathrm{ROA}_{\mathrm{it}}=\alpha+\beta_{1}(\mathrm{CAR})+\beta_{2}(\mathrm{CR})+\beta_{3}(\mathrm{Size})+ \\
\beta_{4}(\mathrm{OE})+\beta_{5}(\mathrm{GDP})+\beta_{6}(\mathrm{CPI})+\beta_{7}(\mathrm{HHI})+\mathrm{u}_{\mathrm{it}}
\end{gathered}
$$

\section{Lagged Dependent Variables}

$$
\begin{gathered}
\mathrm{ROE}_{\mathrm{it}}=\alpha+\theta(\mathrm{ROE})_{\mathrm{t}-1}+\beta_{1}(\mathrm{CAR})+\beta_{2}(\mathrm{CR})+\beta_{3}(\mathrm{Size})+ \\
\beta_{4}(\mathrm{OE})+\beta_{5}(\mathrm{GDP})+\beta_{6}(\mathrm{CPI})+\beta_{7}(\mathrm{HHI})+\mathrm{u}_{\mathrm{it}} \\
\mathrm{ROA}_{\mathrm{it}}=\alpha+\theta(\mathrm{ROA})_{\mathrm{t}-1}+\beta_{1}(\mathrm{CAR})+\beta_{2}(\mathrm{CR})+\beta_{3}(\mathrm{Size})+ \\
\beta_{4}(\mathrm{OE})+\beta_{5}(\mathrm{GDP})+\beta_{6}(\mathrm{CPI})+\beta_{7}(\mathrm{HHI})+\mathrm{u}_{\mathrm{it}}
\end{gathered}
$$

\section{Pooled IV Capital-To-Asset Ratio (CAR) Functions}

\section{No Lagged Dependent Variables}

$$
\begin{aligned}
& \mathrm{CAR}_{\mathrm{it}}=\alpha+\beta_{1}(\mathrm{ROE})+\beta_{2}(\text { Stock })+\beta_{3}(\mathrm{Size})+ \\
& \beta_{4}(\mathrm{CR})+\beta_{5}(\mathrm{GDP})+\beta_{6}(\mathrm{CPI})+\beta_{7}(\mathrm{HHI})+\mathrm{u}_{\mathrm{it}} \\
& \mathrm{CAR}_{\mathrm{it}}=\alpha+\beta_{1}(\mathrm{ROA})+\beta_{2}(\mathrm{Stock})+\beta_{3}(\mathrm{Size})+ \\
& \beta_{4}(\mathrm{CR})+\beta_{5}(\mathrm{GDP})+\beta_{6}(\mathrm{CPI})+\beta_{7}(\mathrm{HHI})+\mathrm{u}_{\mathrm{it}}
\end{aligned}
$$

\section{Lagged Dependent Variables}

$$
\begin{gathered}
\mathrm{CAR}_{\text {it }}=\alpha+\theta(\mathrm{CAR})_{\mathrm{t}-1}+\beta_{1}(\mathrm{ROE})+\beta_{2}(\mathrm{CR})+\beta_{3}(\mathrm{Size})+ \\
\beta_{4}(\text { Stock })+\beta_{5}(\mathrm{GDP})+\beta_{6}(\mathrm{CPI})+\beta_{7}(\mathrm{HHI})+\mathrm{u}_{\mathrm{it}} \\
\mathrm{CAR}_{\mathrm{it}}=\alpha+\theta(\mathrm{CAR})_{\mathrm{t}-1}+\beta_{1}(\mathrm{ROA})+\beta_{2}(\mathrm{CR})+\beta_{3}(\mathrm{Size})+ \\
\beta_{4}(\mathrm{Stock})+\beta_{5}(\mathrm{GDP})+\beta_{6}(\mathrm{CPI})+\beta_{7}(\mathrm{HHI})+\mathrm{u}_{\mathrm{it}}
\end{gathered}
$$




\section{GMM Capital-To-Asset (CAR) Functions}

\section{No Lagged Dependent Variables}

$$
\begin{gathered}
\mathrm{CAR}_{\text {it }}=\alpha+\beta_{1}(\mathrm{ROE})+\beta_{2}(\text { Stock })+\beta_{3}(\mathrm{Size})+ \\
\beta_{4}\left(\mathrm{~S} \_S i z e_{-}\right)+\beta_{5}(\mathrm{CR})+\beta_{6}(\mathrm{GDP})+\beta_{7}(\mathrm{CPI})+\mathrm{u}_{\text {it }} \\
\mathrm{CAR}_{\text {it }}=\alpha+\beta_{1}(\mathrm{ROA})+\beta_{2}(\mathrm{Stock})+\beta_{3}(\mathrm{Size})+ \\
\beta_{4}\left(\mathrm{~S} \_ \text {Size }\right)+\beta_{5}(\mathrm{CR})+\beta_{6}(\mathrm{GDP})+\beta_{7}(\mathrm{CPI})+\mathrm{u}_{\mathrm{it}}
\end{gathered}
$$

\section{Lagged Dependent Variables}

$$
\begin{gathered}
\mathrm{CAR}_{\text {it }}=\alpha+\theta(\mathrm{CAR})_{\mathrm{t}-1}+\beta_{1}(\mathrm{ROE})+\beta_{2}(\mathrm{CR})+\beta_{3}(\mathrm{Size})+ \\
\beta_{4}(\text { Stock })+\beta_{5}(\mathrm{GDP})+\beta_{6}(\mathrm{CPI})+\beta_{7}(\mathrm{HHI})+\mathrm{u}_{\text {it }} \\
\mathrm{CAR}_{\text {it }}=\alpha+\theta(\mathrm{CAR})_{\mathrm{t}-1}+\beta_{1}(\mathrm{ROA})+\beta_{2}(\mathrm{CR})+\beta_{3}(\mathrm{Size})+ \\
\beta_{4}(\text { Stock })+\beta_{5}(\mathrm{GDP})+\beta_{6}(\mathrm{CPI})+\beta_{7}(\mathrm{HHI})+\mathrm{u}_{\mathrm{it}}
\end{gathered}
$$

\section{Results and Data Analysis}

The results provided include the summary descriptive statistics, a description of the Hausman diagnostic tests performed to determine the suitability of using either the panel random effects (RE) model or fixed effects (FE) model, as well as pooled IV and GMM profitability and capital ratio regressions.

With the Jareque-Bera statistics presented in Table 2, the results showed that the data for all the variables used for econometric estimation suffered from non-normality. The data that demonstrated normality in terms of distribution was only the capital-to-asset ratio (CAR) variable. 
Bank Capital and Profitability: An Empirical Study of South African Commercial Banks

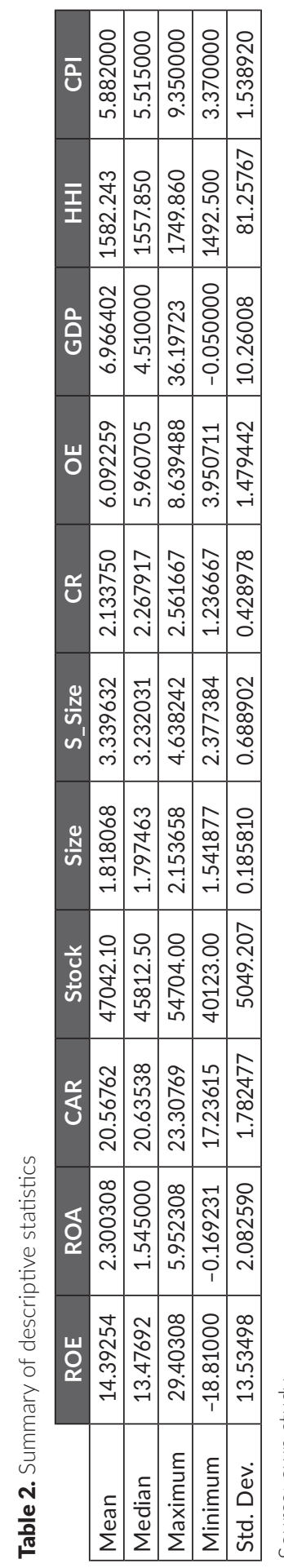




\section{Panel Two-Stage Least Squares (2SLS) Profitability egressions}

The pooled IV or panel 2SLS profitability regressions for ROE and ROA were provided for two models for each distinct aforementioned dependent variable, with no-lagged dependent variable and with a lagged dependent variable.

Table 3. Pooled IV (panel 2SLS) profitability regression estimates

\begin{tabular}{|c|c|c|c|c|}
\hline & \multicolumn{2}{|c|}{ No_Lagged Dependent Variable } & \multicolumn{2}{|c|}{ Lagged Dependent Variable } \\
\hline Dependent Variable & $\mathrm{ROE}_{\mathrm{it}}$ & $\mathrm{ROA}_{\mathrm{it}}$ & $\mathrm{ROE}_{\mathrm{it}}$ & $\mathrm{ROA}_{\mathrm{it}}$ \\
\hline $\mathrm{ROE}_{i t}(-1)$ & - & - & $\begin{array}{c}0.298868 \\
(1.340628)\end{array}$ & - \\
\hline $\mathrm{ROA}_{\mathrm{it}}(-1)$ & - & - & - & $\begin{array}{l}-0.097688 \\
(-1.216327)\end{array}$ \\
\hline CAR & $\begin{array}{c}5.830349 \\
(14.73369)^{* *}\end{array}$ & $\begin{array}{c}0.596809 \\
(18.96896)^{* *}\end{array}$ & $\begin{array}{c}5.779210 \\
(16.53620)^{* *}\end{array}$ & $\begin{array}{c}0.595375 \\
(20.41728)^{* *}\end{array}$ \\
\hline CR & $\begin{array}{l}-45.10305 \\
(-12.70765)^{* *}\end{array}$ & $\begin{array}{c}-5.475841 \\
(-19.40445)^{* *}\end{array}$ & $\begin{array}{l}-51.74057 \\
(-8.525996)^{* *}\end{array}$ & $\begin{array}{c}-5.286771 \\
(-17.23486)^{* *}\end{array}$ \\
\hline Size & $\begin{array}{l}132.5121 \\
(10.31676)^{* *}\end{array}$ & $\begin{array}{c}7.114527 \\
(6.966673)^{* *}\end{array}$ & $\begin{array}{l}115.7207 \\
(3.917717)^{* *}\end{array}$ & $\begin{array}{l}9.249195 \\
(4.871195)^{* *}\end{array}$ \\
\hline OE & $\begin{array}{c}-3.401030 \\
(-8.526199)^{* *}\end{array}$ & $\begin{array}{c}0.255498 \\
(8.056092)^{* *}\end{array}$ & $\begin{array}{l}-4.762812 \\
(-8.028906)^{* *}\end{array}$ & $\begin{array}{c}0.320219 \\
(10.67821)^{* *}\end{array}$ \\
\hline GDP & $\begin{array}{c}0.346044 \\
(5.275728)^{* *}\end{array}$ & $\begin{array}{c}0.083888 \\
(16.08588)^{* *}\end{array}$ & $\begin{array}{c}0.078266 \\
(0.842268)\end{array}$ & $\begin{array}{c}0.102977 \\
(12.04399)^{* *}\end{array}$ \\
\hline CPI & $\begin{array}{c}0.704693 \\
(2.006864)^{* *}\end{array}$ & $\begin{array}{c}0.132635 \\
(4.750804)^{* *}\end{array}$ & $\begin{array}{l}-2.033763 \\
(-2.470286)^{* *}\end{array}$ & $\begin{array}{c}0.336698 \\
(5.297106)^{* *}\end{array}$ \\
\hline $\mathrm{HHI}$ & $\begin{array}{l}-0.149210 \\
(-9.674001)^{* *}\end{array}$ & $\begin{array}{l}-0.008943 \\
(-7.292824)^{* *}\end{array}$ & $\begin{array}{l}-0.104705 \\
(-3.832218)^{* *}\end{array}$ & $\begin{array}{l}-0.012665 \\
(-6.010811)^{* *}\end{array}$ \\
\hline $\mathrm{R}^{2}$ & 0.845828 & 0.958835 & 0.887662 & 0.965789 \\
\hline Adj. $R^{2}$ & 0.838307 & 0.956827 & 0.880447 & 0.963592 \\
\hline S.E. of regression & 5.442558 & 0.432725 & 4.755185 & 0.382941 \\
\hline DW statistic & 2.305492 & 2.971529 & 2.550433 & 3.529038 \\
\hline Instrument rank & 8 & 8 & 9 & 9 \\
\hline Mean dependent var & 14.39254 & 2.300308 & 13.18983 & 2.019487 \\
\hline S.D. dependent var & 13.53498 & 2.082590 & 13.75269 & 2.006949 \\
\hline Sum squared resid & 3643.436 & 23.03184 & 2464.685 & 15.98420 \\
\hline Second-Stage SSR & 3643.436 & 23.03184 & 2464.685 & 15.98420 \\
\hline
\end{tabular}

Source: own study.

The results presented in Table 3 show that CAR had a statistically significant and positive effect on both ROE and ROA in both scenarios where the dependent variable (CAR) was not lagged and when the dependent variable (CAR) was lagged. The results showed that the statistically significant and positive effect of CAR was more pronounced on ROE relative to ROA in both panels. In the scenario where CAR was not lagged, the results revealed that a $1 \%$ increase in CAR led to an increase in ROE, of about $5.8 \%$ and a rise of about.6\% in ROA during the sample period from 2006 
to 2015. Similar results were also found in the scenario where CAR was lagged, for which results show that a $1 \%$ increase in CAR led to an approximately $5.8 \%$ rise in $\mathrm{ROE}$ and a $0.6 \%$ rise in ROA across banks during the period from 2006 to 2015.

Credit risk (CR) demonstrated a statistically significant and negative effect on both ROE and ROA in both scenarios with and without the dependent variable lagged. Similarly, size had a significant and positive effect on both ROE and ROA, while the Herfindahl-Hirschman Index (HHI) consistently had significant and negative effects on both ROE and ROA in both scenarios with and without the lagged dependent variable. Furthermore, operating expenses (OE) consistently had significant and negative effects on ROE, and a significant and positive effect on ROA. Except for the panel where ROE was lagged on itself where GDP had a positive but insignificant effect, GDP had a significant and positive effect on both ROE and ROA. The CPI consistently had significant and positive effects on both ROE and ROA, except for the panel where ROE was lagged. In the panel where ROE was lagged on itself, where the effect of GDP was positive but insignificant, GDP had significant and positive effects on ROE and ROA. In the lagged dependent variable panel, lagged ROE had a positive but insignificant effect on itself, while ROA had a negative but insignificant effect on itself.

\section{GMM Profitability Regressions}

Table 4. GMM profitability regression estimates

\begin{tabular}{|c|c|c|c|c|}
\hline & \multicolumn{2}{|c|}{ No-Lagged Dependent Variable } & \multicolumn{2}{|c|}{ Lagged Dependent Variable } \\
\hline Dependent Variable & $\mathrm{ROE}_{\mathrm{it}}$ & $\mathrm{ROA}_{\mathrm{it}}$ & $\mathrm{ROE}_{\mathrm{it}}$ & $\mathrm{ROA}_{\mathrm{it}}$ \\
\hline $\mathrm{ROE}_{\mathrm{it}}(-1)$ & - & - & $\begin{array}{c}0.298868 \\
(1.340628)\end{array}$ & - \\
\hline $\operatorname{ROA}_{i t}(-1)$ & - & - & - & $\begin{array}{l}-0.097688 \\
(-1.216326)\end{array}$ \\
\hline CAR & $\begin{array}{c}5.830349 \\
(14.73369)^{* *}\end{array}$ & $\begin{array}{c}0.596809 \\
(18.96896)^{* *}\end{array}$ & $\begin{array}{c}5.779210 \\
(16.53620)^{* *}\end{array}$ & $\begin{array}{c}0.595375 \\
(20.41728)^{* *}\end{array}$ \\
\hline CR & $\begin{array}{l}-45.10305 \\
(-12.70765)^{* *}\end{array}$ & $\begin{array}{c}-5.475841 \\
(-19.40445)^{* *}\end{array}$ & $\begin{array}{l}-51.74057 \\
(-8.525996)^{* *}\end{array}$ & $\begin{array}{c}-5.286771 \\
(-17.23486)^{* *}\end{array}$ \\
\hline Size & $\begin{array}{l}132.5121 \\
(10.31676)^{* *}\end{array}$ & $\begin{array}{l}7.114527 \\
(6.966673)^{* *}\end{array}$ & $\begin{array}{l}115.7207 \\
(3.917717)^{* *}\end{array}$ & $\begin{array}{l}9.249196 \\
(4.871195)^{* *}\end{array}$ \\
\hline OE & $\begin{array}{l}-3.401030 \\
(-8.526199)^{* *}\end{array}$ & $\begin{array}{c}0.255498 \\
(8.056092)^{* *}\end{array}$ & $\begin{array}{l}-4.762812 \\
(-8.028906)^{* *}\end{array}$ & $\begin{array}{c}0.320219 \\
(10.67821)^{* *}\end{array}$ \\
\hline GDP & $\begin{array}{c}0.346044 \\
(5.275728)^{* *}\end{array}$ & $\begin{array}{c}0.083888 \\
(16.08588)^{* *}\end{array}$ & $\begin{array}{c}0.078266 \\
(0.842268)\end{array}$ & $\begin{array}{c}0.102977 \\
(12.04399)^{* *}\end{array}$ \\
\hline CPI & $\begin{array}{l}0.704693 \\
(2.006864)^{* *}\end{array}$ & $\begin{array}{c}0.132635 \\
(4.750804)^{* *}\end{array}$ & $\begin{array}{l}-2.033763 \\
(-2.470286)^{* *}\end{array}$ & $\begin{array}{c}0.336698 \\
(5.297106)^{* *}\end{array}$ \\
\hline $\mathrm{HHI}$ & $\begin{array}{l}-0.149210 \\
(-9.674001)^{* *}\end{array}$ & $\begin{array}{l}-0.008943 \\
(-7.292824)^{* *}\end{array}$ & $\begin{array}{l}-0.104705 \\
(-3.832218)^{* *}\end{array}$ & $\begin{array}{l}-0.012665 \\
(-6.010811)^{* *}\end{array}$ \\
\hline $\mathrm{R}^{2}$ & 0.845828 & 0.958835 & 0.887662 & 0.965789 \\
\hline Adj. $\mathrm{R}^{2}$ & 0.838307 & 0.956827 & 0.880447 & 0.963592 \\
\hline
\end{tabular}


No-Lagged Dependent Variable

\section{Dependent Variable}

S.E. of regression

DW statistic

Instrument rank

Mean dependent var

S.D. dependent var

Sum squared resid

J-statistic
$\mathrm{ROE}_{\mathrm{it}}$

5.442558

2.305492

\begin{tabular}{l|l}
8 & 8 \\
\hline
\end{tabular}

14.39254

13.53498

3643.436

26.46790
ROA $_{\text {it }}$

0.432725

2.971529

2.300308

\begin{tabular}{l|l}
8 & \\
\hline
\end{tabular}

\begin{tabular}{|c|c|c|}
\hline 2.082590 & 13.75269 & 2.006949 \\
\hline 23.03184 & 2464.685 & 15.98420 \\
\hline 28.23871 & 109.0000 & 109.0000 \\
\hline
\end{tabular}

Source: own study.

The estimated results in Table 4 revealed that the capital-to-asset ratio (CAR) consistently demonstrated statistically significant and positive effects on both ROE and ROA in both scenarios with and without the dependent variable (CAR) lagged on itself. The computed econometric estimates show that the statistically significant and positive effect of CAR was more noticeable on ROE comparative to ROA in both scenarios. In the scenario where CAR was not lagged, the results reveal that a $1 \%$ increase in CAR led to an approximately $5.8 \%$ increase in ROE, and about a $0.6 \%$ rise in ROA during the sample period from 2006 to 2015. Similar results were also obtained in the scenario where CAR was lagged, for which the estimated results show that a $1 \%$ increase in CAR led to an approximately $5.8 \%$ rise in ROE and about a $0.6 \%$ rise in ROA across banks during the sample period 2006 to 2015 under review.

Consistent with the results obtained using the panel 2SLS method credit risk (CR) recurrently had statistically significant and negative effects on both ROE and ROA both with and without the dependent variable lagged. Likewise, size consistently had statistically significant and positive effects on both ROE and ROA, while the Herfindahl-Hirschman Index (HHI) consistently had significant and negative effects on both $\mathrm{ROE}$ and ROA in both scenarios with and without the lagged dependent variable. Conversely, OE consistently had a significant and negative effect on ROE, but a significant and positive effect on ROA in both scenarios with and without the lagged dependent variable.

With the exception of the panel where ROE was lagged on itself, where GDP had a positive but insignificant effect, GDP had statistically significant and positive effects on both ROE and ROA. The consumer price index (CPI) had statistically significant and positive effects on both ROE and ROA, except for the panel where ROE was lagged. In the panel where ROE was lagged on itself, where the effect of GDP was positive but insignificant, GDP had a significant and positive effect on ROE and ROA. In the lagged dependent variable panel, lagged ROE had a positive but insignificant effect on itself, while ROA had a negative but statistically insignificant effect on itself. The adjusted R-square values showed that more than $84 \%$ of overall variation in each of the distinct models of ROE and ROA were explained by the independent variables captured in the respective estimated models. 


\section{Pooled IV Capital-To-Asset Ratio (CAR) Regression Estimates}

Table 5. Pooled IV capital-to-asset ratio (CAR) regression estimates

\begin{tabular}{|c|c|c|c|c|}
\hline & \multicolumn{2}{|c|}{ No-Lagged Dependent Variable } & \multicolumn{2}{|c|}{ Lagged Dependent Variable } \\
\hline \multicolumn{5}{|c|}{ Dependent Variable: Capital-to-Asset Ratio $\left(C A R_{i t}\right)$} \\
\hline Endogenous Regressor & $\mathrm{ROE}_{\mathrm{it}}$ & $\mathrm{ROA}_{\mathrm{it}}$ & $\mathrm{ROE}_{\mathrm{it}}$ & $\mathrm{ROA}_{\text {it }}$ \\
\hline $\mathrm{ROE}_{\mathrm{it}}$ & $\begin{array}{r}0.080634 \\
(10.61961)^{* *}\end{array}$ & - & $\begin{array}{l}0.076476 \\
(7.509609)^{* *}\end{array}$ & - \\
\hline $\mathrm{ROA}_{\text {it }}$ & - & $\begin{array}{c}1.067740 \\
(11.72807)^{* *}\end{array}$ & - & $\begin{array}{c}1.239563 \\
(7.438631)^{* *}\end{array}$ \\
\hline $\mathrm{CAR}_{\mathrm{it}}(-1)$ & - & - & $\begin{array}{c}0.175374 \\
(2.435605)^{* *}\end{array}$ & $\begin{array}{l}-0.149296 \\
(-1.781099) \\
\end{array}$ \\
\hline Stock & $\begin{array}{c}5.32 \mathrm{E}-05 \\
(2.921201)^{* *}\end{array}$ & $\begin{array}{c}2.37 E-05 \\
(1.289580)\end{array}$ & $\begin{array}{c}0.000156 \\
(6.203385)^{* *}\end{array}$ & $\begin{array}{c}0.000131 \\
(4.920064)^{* *}\end{array}$ \\
\hline Size & $\begin{array}{l}-25.94389 \\
(-27.34569)^{* *} \\
\end{array}$ & $\begin{array}{l}-15.55784 \\
(-12.51505)^{* *} \\
\end{array}$ & $\begin{array}{c}-7.760979 \\
(-9.121174)^{* *} \\
\end{array}$ & $\begin{array}{l}-3.835543 \\
(-3.661240)^{* *} \\
\end{array}$ \\
\hline CR & $\begin{array}{c}8.317196 \\
(29.71585)^{* *}\end{array}$ & $\begin{array}{c}7.464892 \\
(29.77775)^{* *}\end{array}$ & $\begin{array}{c}8.069960 \\
(13.35642)^{* *}\end{array}$ & $\begin{array}{c}8.794265 \\
(13.87024)^{* *}\end{array}$ \\
\hline GDP & $\begin{array}{l}-0.077248 \\
(-9.251632)^{* *}\end{array}$ & $\begin{array}{r}-0.099543 \\
(-11.98143)^{* *} \\
\end{array}$ & $\begin{array}{r}0.016483 \\
(1.473551) \\
\end{array}$ & $\begin{array}{l}-0.055301 \\
(-3.692038)^{* *}\end{array}$ \\
\hline CPI & $\begin{array}{c}0.172665 \\
(3.088658)^{* *}\end{array}$ & $\begin{array}{c}-0.089134 \\
(-1.394276) \\
\end{array}$ & $\begin{array}{l}0.794479 \\
(7.977027)^{* *} \\
\end{array}$ & $\begin{array}{c}0.481796 \\
(4.130103)^{* *}\end{array}$ \\
\hline $\mathrm{HHI}$ & $\begin{array}{c}0.028974 \\
(23.10186)^{* *}\end{array}$ & $\begin{array}{c}0.019322 \\
(14.13415)^{* *}\end{array}$ & - & - \\
\hline $\mathrm{R}^{2}$ & 0.811018 & 0.828986 & 0.694072 & 0.692109 \\
\hline Adj. $\mathrm{R}^{2}$ & 0.801799 & 0.820643 & 0.677385 & 0.675315 \\
\hline S.E. of regression & 0.793554 & 0.754888 & 1.066276 & 1.069692 \\
\hline DW statistic & 3.484970 & 2.785397 & 3.536202 & 3.076812 \\
\hline Instrument rank & 8 & 8 & 8 & 8 \\
\hline Mean dependent var & 20.56762 & 20.56762 & 20.53752 & 20.53752 \\
\hline S.D. dependent var & 1.782477 & 1.782477 & 1.877274 & 1.877274 \\
\hline Sum squared resid & 77.45646 & 70.09226 & 125.0639 & 125.8665 \\
\hline Second-Stage SSR & 77.45646 & 70.09226 & 125.0639 & 125.8665 \\
\hline
\end{tabular}

Source: own study.

The computed results presented in Table 5 indicated that both the ROE and ROA endogenous variables had statistically significant and positive effects on the capital-to-asset (CAR) ratio of commercial banks in South Africa during the period from 2006 to 2015. These results remained consistent in both scenarios where the dependent variable (CAR) was not lagged and where the dependent variable (CAR) was lagged. The results showed that the statistically significant and positive effect of both ROE and ROA endogenous variables were moderately different in terms of magnitude in both panels. In the scenario where CAR was not lagged, the results revealed that a $1 \%$ increase in $\mathrm{ROE}$ led to about a $0.1 \%$ increase in CAR, while a $1 \%$ increase in ROA led to about a $1.1 \%$ rise in CAR during the period under review. Similar results were also 
found in the scenario where CAR was lagged, for which results showed that a $1 \%$ increase in ROE led to an approximately $0.1 \%$ rise in CAR, while a $1 \%$ rise in ROA led to approximately $1.2 \%$ upsurge in CAR across the sampled commercial banks in South Africa during the period from 2006 to 2015. In general, the results show that ROA had a more pronounced significant and positive effect on CAR compared to ROE during the sample period.

Stock had statistically significant and positive effects on both ROE and ROA in both scenarios with and without the dependent variable lagged; with the exception of the scenario where the dependent variable CAR was not lagged in which stock had a positive but statistically insignificant effect. Size continually had statistically significant and negative effects on both ROE and ROA in both scenarios with and without the dependent variable CAR lagged. By contrast, credit risk (CR) consistently had statistically significant and positive effects on both ROE and ROA, while the Herfindahl Hirschman Index (HHI) had significant and positive effects on both ROE and ROA only in the scenario where the dependent variable CAR was not lagged.

In the scenario where the dependent variable CAR was lagged with ROE being the endogenous variable, lagged CAR had a statistically significant and positive effect on CAR. Nonetheless, in the scenario where the dependent variable CAR was lagged with ROA being the endogenous variable, lagged CAR had a statistically insignificant and negative effect on CAR of commercial banks in South Africa during the sample period. The estimated adjusted R-square values showed that more than $80 \%$ of overall variation in each of the distinct models of ROE and ROA in which the dependent variable CAR was not lagged was explained by the independent variables captured in the respective models. In the case of the scenario where the dependent variable CAR was lagged, about $67 \%$ of overall variations in CAR for each of the models where ROE and ROA were distinct endogenous variables were explained by the independent variables captured in the respective estimated models.

\section{GMM Capital -To-Asset Ratio Regressions}

In Table 6, the results showed that both ROE and ROA had statistically significant and positive effects on CAR. Results revealed that a $1 \%$ increase in ROE led to about a $0.05 \%$ increase in CAR, while a $1 \%$ increase in ROA led to about a $0.5 \%$ rise in CAR. Stock had a significant and negative effect on CAR in both models where ROE and ROA were discretely endogenous variables. Conversely, size consistently had a statistically significant and positive effect on CAR in both scenarios where ROE and ROA were individually endogenous variables. Size had a more pronounced significant and positive effect on CAR in the scenario where ROE was the endogenous variable relative to the scenario where ROA was the endogenous variable. 
Table 6. GMM capital-to-asset ratio regressions

\begin{tabular}{|c|c|c|}
\hline & \multicolumn{2}{|c|}{ No_Lagged Dependent Variable } \\
\hline \multicolumn{3}{|c|}{ Dependent Variable: Capital-to-Asset Ratio $\left(\mathrm{CAR}_{\mathrm{it}}\right)$} \\
\hline Endogenous Regressor & $\mathrm{ROE}_{\mathrm{it}}$ & $\mathrm{ROA}_{\mathrm{it}}$ \\
\hline $\mathrm{ROE}_{\text {it }}$ & $\begin{array}{c}0.049665 \\
(6.881929)^{* *}\end{array}$ & - \\
\hline $\mathrm{ROA}_{\text {it }}$ & - & $\begin{array}{c}0.492363 \\
(3.552498)^{* *}\end{array}$ \\
\hline Stock & $\begin{array}{l}-0.000119 \\
(-5.279644)^{* *}\end{array}$ & $\begin{array}{c}-7.88 \mathrm{E}-05 \\
(-3.222354)^{* *}\end{array}$ \\
\hline Size & $\begin{array}{c}33.26938 \\
(18.47303)^{* *}\end{array}$ & $\begin{array}{c}27.71804 \\
(10.68559)^{* *}\end{array}$ \\
\hline S_Size & $\begin{array}{l}-10.83750 \\
(-24.39309)^{* *}\end{array}$ & $\begin{array}{r}-8.886040 \\
(-11.45589)^{* *} \\
\end{array}$ \\
\hline CR & $\begin{array}{c}1.089316 \\
(3.049654)^{* *}\end{array}$ & $\begin{array}{c}1.756347 \\
(3.256539)^{* *}\end{array}$ \\
\hline GDP & $\begin{array}{c}0.038086 \\
(4.676206)^{* *}\end{array}$ & $\begin{array}{c}0.009355 \\
(0.725114) \\
\end{array}$ \\
\hline CPI & $\begin{array}{l}-0.246623 \\
(-3.820660)^{* *}\end{array}$ & $\begin{array}{l}-0.235701 \\
(-3.180899)^{* *} \\
\end{array}$ \\
\hline $\mathrm{R}^{2}$ & 0.827159 & 0.782884 \\
\hline Adj. $R^{2}$ & 0.818728 & 0.772293 \\
\hline S.E. of regression & 0.758908 & 0.850574 \\
\hline DW statistic & 3.775941 & 3.229470 \\
\hline Instrument rank & 8 & 8 \\
\hline Mean dependent var & 20.56762 & 20.56762 \\
\hline S.D. dependent var & 1.782477 & 1.782477 \\
\hline Sum squared resid & 70.84083 & 88.98755 \\
\hline Second-Stage SSR & 2.169845 & 2.637106 \\
\hline
\end{tabular}

Source: own study.

Furthermore, the effect of the credit risk (CR) on CAR was statistically significant and positive, and remained almost of the same magnitude in both scenarios where ROE and ROA were distinctive endogenous variables. The effect of GDP on CAR was positive for both scenarios where ROE and ROA were endogenous variables, but only statistically significant where ROE was the endogenous variable. The effect of CPI on CR was statistically significant and negative, and remained nearly of the same magnitude in both scenarios where ROE and ROA were distinctive endogenous variables. The adjusted R-square values showed that the independent variables explained about $82 \%$ of the overall variation in CAR for the model in which ROE was the endogenous variable. Similarly, the same independent variables explained about $78 \%$ of the overall variation in CAR for the model in which ROA was the endogenous variable. 


\section{Conclusions}

The literature discusses and debates issues of capital intensely. Regulators have made it a focal point and of late, shareholders and other stakeholders have brought both return on capital and return on assets to the fore in their investment decision-making processes. Banks are encouraged to view both capital and its management as key performance indicators going into the future. The management or mismanagement of capital can determine a bank's competitiveness.

Banks are under pressure to show more profits (Nyoka 2013) and the temptation to underprovide for non-performing loans is very high. As banks become desperate to report higher returns on both equity and assets (and thus increase capital ratios through retained earnings in both the near and longer term) it is up to policy-makers, especially those that are in the supervision sphere, to continuously review banking practices and to report on such important issues as provisions for bad loans. It is recommended, therefore, that policy-makers should be on their guard and must at least devise mechanisms to monitor these provisions by putting a threshold in place as a guide and to improve the quality of staff at the regulating institutions.

\section{References}

Afanasieff, T., Lhacer, P., Nakane, M. (2002), The determinants of bank interest Spreads in Brazil, Banco Central di Brazil Working Papers.

Akinboade, O.S., Makina, D. (2006), Financial sector development in South Africa, 1970 2002, "Journal of Studies in Economics and Econometrics", Vol. 30 (1), pp. 101-128.

Anbar, A., Alper, D. (2011), Bank specific and macroeconomic determinants of commercial bank profitability: Empirical evidence from Turkey, "Business and Economics Research Journal", Vol. 2, No. 2, pp. 139-152.

Athanasoglou, P.P., Brissimis, S.N., Delis, M.D. (2008), Bank-specific, industry-specific and macroeconomic determinants of bank profitability, "Journal of International Financial Markets, Institutions and Money”, Vol. 18, No. 2, pp. 121-136.

Athanasoglou, P.P., Delis, M.D., Staikouras, C.K. (2006), Determinants of bank profitability in the South-Eastern European region. Bank of Greece, MPRA working Paper No. 10274. Bank of Greece. Retrieved from: http://mpra.ub.unimuenchen. de/10274/1/MPRA_paper_10274.pdf (accessed: 10.08.2011).

Berger, A.N. (1995), The relationship between capital and earnings in banking, "Journal of Money, Credit and Banking”, Vol. 27 (2), pp. 432-456.

Berger, A.N., Black, L. (2011), Bank size, lending technologies and small business finance, Journal of Banking and Finance, No. 35, pp. 724-735.

Berger, A.N., Hanweck, G.A., Humphrey, D.B. (1987), Competitive Viability in Banking: Scale, Scope and Product Mix Economies, "Journal of Monetary Economics", No. 20m, pp. 501-520.

Berger, A.N., Herring, R.J., Szego, G.P. (1995), The role of capital in financial institutions, "Journal of Banking and Finance", Vol. 19 (3/4), pp. 393-430. 
Berger, A.N., Herring, R.J., Szego, G.P. (1995), The Role of Capital in Financial institutions. "Journal of Banking and Finance", Vol. 19, No. 3-4, pp. 393-430.

Ćuraka, M., Poposkib, K., Pepura, S. (2011), Profitability Determinants of the Macedonian Banking Sector in Changing Environments, Skopje: Published by Elsevier Ltd.

Demirguc-Kunt, A., Huizinga, H. (1999), Determinants of commercial bank interest margins and profitability: Some international evidence, The World Bank Economic Review, Vol. 13, No. 2, pp. 379-408.

Dietrich, A., Wanzenried, G. (2008), Determinants of bank profitability before and during the crisis: Evidence from Switzerland, "Journal of International Financial Markets, Institutions and Money”, No. 21 (3), pp. 307-327.

Dietrich, A., Wanzenried, G. (2009), What determines the profitability of commercial banks? New evidence from Switzerland, Paper delivered at the $12^{\text {th }}$ Conference of the Swiss Society for Financial Market Researches, Geneva, DOI: 10.1111/00221082.00084.

Flamini, V., McDonald, C., Schumacher, L. (2009), The determinants of commercial bank profitability in Sub-Saharan Africa, IMF Working paper WP/09/15, Retrieved from: http://www.finmarktrust.org.za (accessed: 25.04.2011).

Goddard, J., Molyneux, P., Wilson, J. (2004), The profitability of European banks: A cross -sectional and dynamic panel analysis, The Manchester School, Vol. 72 (3), pp. 363-381.

Gungor, B. (2007), Türkiye’de Faaliyet Gösteren Yerel ve Yabancı Bankaların Karlılık Seviyelerini Etkileyen Faktörler: Panel Veri Analizi. İktisat İşletme ve Finans, Vol. 22 (258), pp. 40-63.

Javaid, S., Anwar, J., Zaman, K., Gafoor, A. (2011), Determinants of bank profitability in Pakistan: Internal factor analysis, "Mediterranean Journal of Social Sciences", Vol. 2 (1), pp. 59-78.

Kahane, Y. (1977), Capital Adequacy and the Regulation of Financial Intermediaries, "Journal of Banking and Finance", No. 1, pp. 207-218.

Kaufman, G.G. (1991), Capital in Banking: Past, Present and Future, "Journal of Financial Services Research”, No. 5, pp. 385-402.

Keeley M.C., Furlong, F.T. (1990), A Re-examination of Mean Variance Analysis of Bank Capital Regulations, "Journal of Banking and Finance", No. 14, pp. 69-84.

Kosmidou, K. (2008), The determinants of banks' profits in Greece during the period of EU financial integration, "Managerial Finance", Vol. 34 (3), pp. 146-159.

KPMG, Bank margins and related profitability in South Africa, 20 November 1998.

Mamatzakis, E.C., Remoundos, P.C. (2003), Determinants of Greek commercial banks profitability, 1989-2000. SPOUDAI, Vol. 53 (1), pp. 94-94.

Molyneux, P., Thornton, J. (1992), Determinants of European bank profitability: A note, "Journal of Banking and Finance", No. 16, pp. 1173-1178.

Naceur, S.B. (2003), The determinants of the Tunisian banking industry profitability: panel evidence, Working Paper, Department of Finance, University Libre de Tunis, Tunisia, October 1993.

Ngo, PT.H. (2006), Endogenous Capital and Profitability in Banking, Working Paper No. 464. ISBN 0-86831-464, 1 May 23, 2006. 
Nyoka, C. (2013), Are banks charges a threat or opportunity to banks' intermediation function? The case of South Africa, "International Journal of Business, Accounting, and Finance", Vol. 7 (Number 2).

Short, B. (1979), The relationship between commercial bank profit rates and banking concentration in Canada, Western Europe and Japan, "Journal of Banking and Finance", No. 3, pp. 209-219.

\section{Streszczenie}

\section{Kapitał bankowy a rentowność: badanie empiryczne południowoafrykańskich banków komercyjnych}

Kapitał bankowy jest zasadniczym aspektem regulacji i określa, jak długo bank utrzyma się na rynku z regulacyjnego punktu widzenia. Wcześniejsze badania dotyczące związku między kapitałem a rentownością w dużej mierze koncentrowały się na gospodarkach rozwiniętych, w szczególności USA i Europie, a ich wyniki były niejednoznaczne. Natomiast jak dotąd brak jest wyników badań dotyczących gospodarek wschodzących, takich jak RPA. Wykorzystując Republikę Południowej Afryki jako przedmiot analizy i stosując Uogólnioną Metodę Momentów (GMM), Podwójną Metodę Najmniejszych Kwadratów (2SLS) lub metodę zmiennych instrumentalnych (Pooled IV method) jako techniki szacowania, w badaniu zweryfikowano hipotezę zakładającą, że istnieje dodatni i statystycznie istotny związek między kapitałem banku a zyskiem. Wyniki analizy dostarczyły dowodów na pozytywny związek między współczynnikiem adekwatności kapitałowej (CAR), rentownością kapitału własnego (ROE) i rentownością aktywów (ROA). Z punktu widzenia podejmowania decyzji strategicznych przez bank wyniki niniejszych badań mogą pomóc instytucjom finansowym i inwestorom w dopasowaniu decyzji inwestycyjnych do polityki państwa dotyczącej kapitału bankowego. Natomiast z punktu widzenia polityki państwa, może pomóc to zarówno rządom, jak i organom regulacyjnym, $w$ formułowaniu bardziej świadomych decyzji dotyczących znaczenia kapitału bankowego.

Słowa kluczowe: kapitał, RPA, zwrot z kapitału, metoda zmiennych instrumentalnych (Pooled IV method), regresja, analiza 